\title{
The Gata3 Transcription Factor Is Required for the Survival of Embryonic and Adult Sympathetic Neurons
}

\author{
Konstantina Tsarovina, ${ }^{1}$ Tobias Reiff, ${ }^{1,4}$ Jutta Stubbusch, ${ }^{1,4}$ Dorota Kurek, ${ }^{2}$ Frank G. Grosveld, ${ }^{2}$ Rosanna Parlato, ${ }^{3}$ \\ Günther Schütz, ${ }^{3}$ and Hermann Rohrer ${ }^{1}$ \\ ${ }^{1}$ Research Group Developmental Neurobiology, Max-Planck-Institute for Brain Research, 60528 Frankfurt/M, Germany, ${ }^{2}$ Department of Cell Biology, \\ Erasmus MC, 3000 DR Rotterdam, The Netherlands, ${ }^{3}$ Department of Molecular Biology of the Cell I, German Cancer Research Center, D-69120 Heidelberg, \\ Germany, and ${ }^{4}$ Institute of Clinical Neuroanatomy, Neuroscience Center, Goethe-University Frankfurt, 60590 Frankfurt/M, Germany
}

The transcription factor Gata3 is essential for the development of sympathetic neurons and adrenal chromaffin cells. As Gata3 expression is maintained up to the adult stage, we addressed its function in differentiated sympathoadrenal cells at embryonic and adult stages by conditional Gata3 elimination. Inactivation of Gata3 in embryonic $D B H$-expressing neurons elicits a strong reduction in neuron numbers due to apoptotic cell death and reduced proliferation. No selective effect on noradrenergic gene expression ( $T H$ and $D B H)$ was observed. Interestingly, Gata3 elimination in $D B H$-expressing neurons of adult animals also results in a virtually complete loss of sympathetic neurons. In the Gata3-deficient population, the expression of anti-apoptotic genes $\left(B c l-2, B c l-x_{L}\right.$, and $\left.N F \kappa B\right)$ is diminished, whereas the expression of pro-apoptotic genes ( $B i k, B o k$, and $B m f)$ was increased. The expression of noradrenergic genes ( $T H$ and $D B H)$ is not affected. These results demonstrate that Gata3 is continuously required for maintaining survival but not differentiation in the sympathetic neuron lineage up to mature neurons of adult animals.

\section{Introduction}

A fundamental aspect of neural development is the specification and maintenance of differentiated neuron types. Specification of neuron fate is mediated by networks of transcription factors that play essential roles in activating target genes of specific neuron fates (Guillemot, 2007). However, it is unclear to what extent these regulatory networks are necessary to maintain specific neuronal properties after development has completed. Terminal selector genes expressed throughout the lifetime of a neuron and required for maintaining its differentiated state have been described in Caenorhabditis elegans (Hobert, 2008). Also, in vertebrates, candidate terminal selector transcription factors were identified (Cheng et al., 2005), including Gata2, which determines postmitotic neuronal identity of midbrain GABAergic neurons (Kala et al., 2009).

From the Gata family of transcription factors, only Gata2 and Gata3 are found in the nervous system in overlapping expression patterns, with important roles in the development of specific neuronal populations, including neurons in the inner ear, midbrain, hindbrain, spinal cord, and sympathoadrenal system. Gata3 is involved in the generation of serotonergic neurons (van Doorninck et al., 1999; Pattyn et al., 2004) and ear formation,

Received Jan. 12, 2010; revised May 31, 2010; accepted June 7, 2010.

H.R. has been supported by grants from the Deutsche Forschungsgemeinschaft, Schram Stiftung, and Wilhelm Sander Stiftung. We thank Uwe Ernsberger for critical comments on the paper, Afsaneh Majdazari for ganglia dissection, and Julia Andres and Sabine Stanzel for excellent technical assistance.

Correspondence should be addressed to Hermann Rohrer, Research Group Developmental Neurobiology, MaxPlanck-Institute for Brain Research, Deutschordenstrasse 46, 60528 Frankfurt/M, Germany. E-mail: rohrer@mpih-frankfurt.mpg.de.

DOI:10.1523/JNEUROSCI.0175-10.2010

Copyright $\odot 2010$ the authors $\quad 0270-6474 / 10 / 3010833-11 \$ 15.00 / 0$ affecting the morphogenesis of the inner ear, axonal navigation of inner ear efferent neurons, and cell survival of outer hair cells (Karis et al., 2001; van der Wees et al., 2004). In the developing sympathoadrenal system Gata3 is essential for differentiation and cell survival (Lim et al., 2000; Tsarovina et al., 2004; Moriguchi et al., 2006).

The initial development of sympathoadrenal cells is regulated by a network of transcription factors, including Phox $2 b$, Ascl1, Hand2, Insm1, and Gata2/3 (Goridis and Rohrer, 2002). Phox2b is essential for initial sympathoadrenal cell specification from neural crest progenitors (Pattyn et al., 1999) and controls, together with Hand2, proliferation and noradrenergic differentiation (Lucas et al., 2006; Morikawa et al., 2007; Hendershot et al., 2008; Schmidt et al., 2009; Reiff et al., 2010). Ascl1 and Insm1 affect proliferation and timing as their elimination results in delayed development and reduced ganglion size but normal differentiation (Pattyn et al., 2006; Wildner et al., 2008; Morikawa et al., 2009). Gata3 controls the initial expression of the noradrenergic marker gene $T H$ but also generic neuronal differentiation and survival (Lim et al., 2000; Tsarovina et al., 2004; Moriguchi et al., 2006). Chromaffin cell development depends in a similar but not identical manner on the same transcriptional regulators identified in sympathetic ganglia (Huber et al., 2009). The continued Gata3 expression in the sympathoadrenal system throughout the lifetime of the animal, together with the essential role of Gata3 in the maintenance of the differentiated state in other lineages (Kouros-Mehr et al., 2006), raises the question as to the role of Gata3 in mature sympathetic neurons and chromaffin cells.

We now demonstrate that Gata3 elimination in both differentiated embryonic and adult sympathetic neurons results in a virtually complete neuron loss by apoptotic cell death. In contrast, 

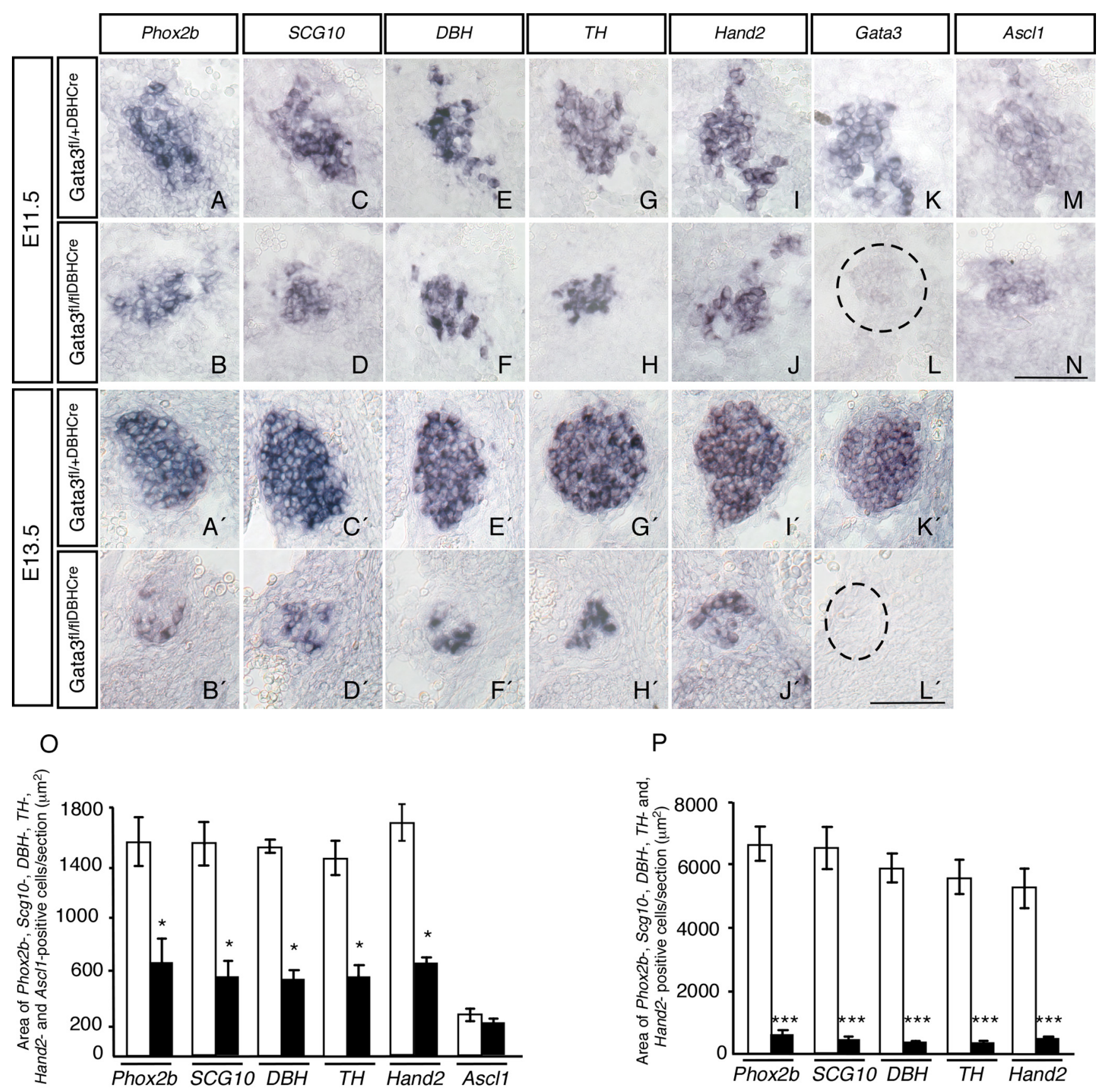

$\square^{\text {Gata3 }}{ }^{\mathrm{fl} / \mathrm{DBHCre}}$

Gata3 ${ }^{\text {fl/flDBHCre }}$

Figure 1. Reduction of sympathetic ganglion size in E11.5 and E13.5 conditional Gata3 mutant mice. The sympathetic ganglion size is reduced in E11.5 sympathetic ganglia of conditional Gata3 knock-out mice as reflected by the reduced expression areas of $\operatorname{Phox} 2 \boldsymbol{b}(\boldsymbol{A}, \boldsymbol{B}), \operatorname{SCG} 10(\boldsymbol{C}, \boldsymbol{D}), D B H(\boldsymbol{E}, \boldsymbol{F}), T H(\boldsymbol{G}, \boldsymbol{H})$, and $\operatorname{Hand2}(\boldsymbol{I}, \boldsymbol{J})$. There was no significant reduction of the area of $A s c l 1-$ expressing cells $(\boldsymbol{M}, \boldsymbol{N})$. The expression of Gata3 was eliminated in the Gata ${ }^{\mathrm{f} / \text { /fDBBHre }}$ sympathetic ganglia $(\boldsymbol{K}, \boldsymbol{L})$. At E13.5, only rudiments of the ganglia were left in Gata3 ${ }^{\mathrm{f} / \text { /flDBHCre }}$ mutants, reflected by the small area of Phox2b- $\left(\boldsymbol{A}^{\prime}, \boldsymbol{B}^{\prime}\right), \mathbf{S C G} 10-\left(\boldsymbol{C}^{\prime}, \mathbf{D}^{\prime}\right), \mathrm{DBH}-\left(\boldsymbol{E}^{\prime}, \boldsymbol{F}^{\prime}\right), T H-\left(\boldsymbol{G}^{\prime}, \boldsymbol{H}^{\prime}\right)$, and Hand2- $\left(\boldsymbol{I}^{\prime}, \boldsymbol{J}^{\prime}\right)$ expressing cells. There was no Gata3 expression detected at E13.5 mutants $\left(\boldsymbol{L}^{\prime}\right)$, indicating that Gata3 was completely knocked out by Cre recombination. The areas of Phox2b, SCG10, DBH, TH, Hand2, and Ascl1 expression at E11.5 and E13.5 are quantified in $\mathbf{O}$ and $\boldsymbol{P}$, respectively [asterisks indicate that values were significantly different compared to controls $\left({ }^{*} p<0.01,{ }^{* * *} p<0.0001 ; n=4\right.$ for E11.5 and $n=6$ for E13.5 (Student's $t$ test)]. Scale bar, $100 \mu \mathrm{m}$.

chromaffin cell survival depends on Gata3 only during embryonic development. Our results indicate a survival function, which is of fundamental importance for the maintenance of the adult sympathetic nervous system.

\section{Materials and Methods}

Animals. Gata $3^{\text {loxP }}$ mice (Kurek et al., 2007) and $\mathrm{DBH}^{\mathrm{Cre}}$ mice (Stanke et al., 2006; Parlato et al., 2007) have been described previously. The DBH ${ }^{\text {CreERT2 }}$ mice were generated as follows: The Cre-ERT2-
PolyA-cassette (Mori et al., 2006) was integrated into a P1-derived bacterial artificial chromosome (BAC) that harbored the gene for mouse $D B H$ (Parlato et al., 2007) using homologous recombination. This construct was integrated in C57BL/6 mice. Specific Cre expression in noradrenergic neurons and chromaffin cells was shown by crossing with the reporter mouse Rosa26R. The generation of DBH ${ }^{\text {CreERT2 }}$ mouse lines is described by J. Stubbusch, A. Majdazari, M. Schmidt, G. Schütz, and H. Rohrer (unpublished observation). Mouse breeding and genotyping was performed as described before (Tsarovina et al., 2004). The embryonic 

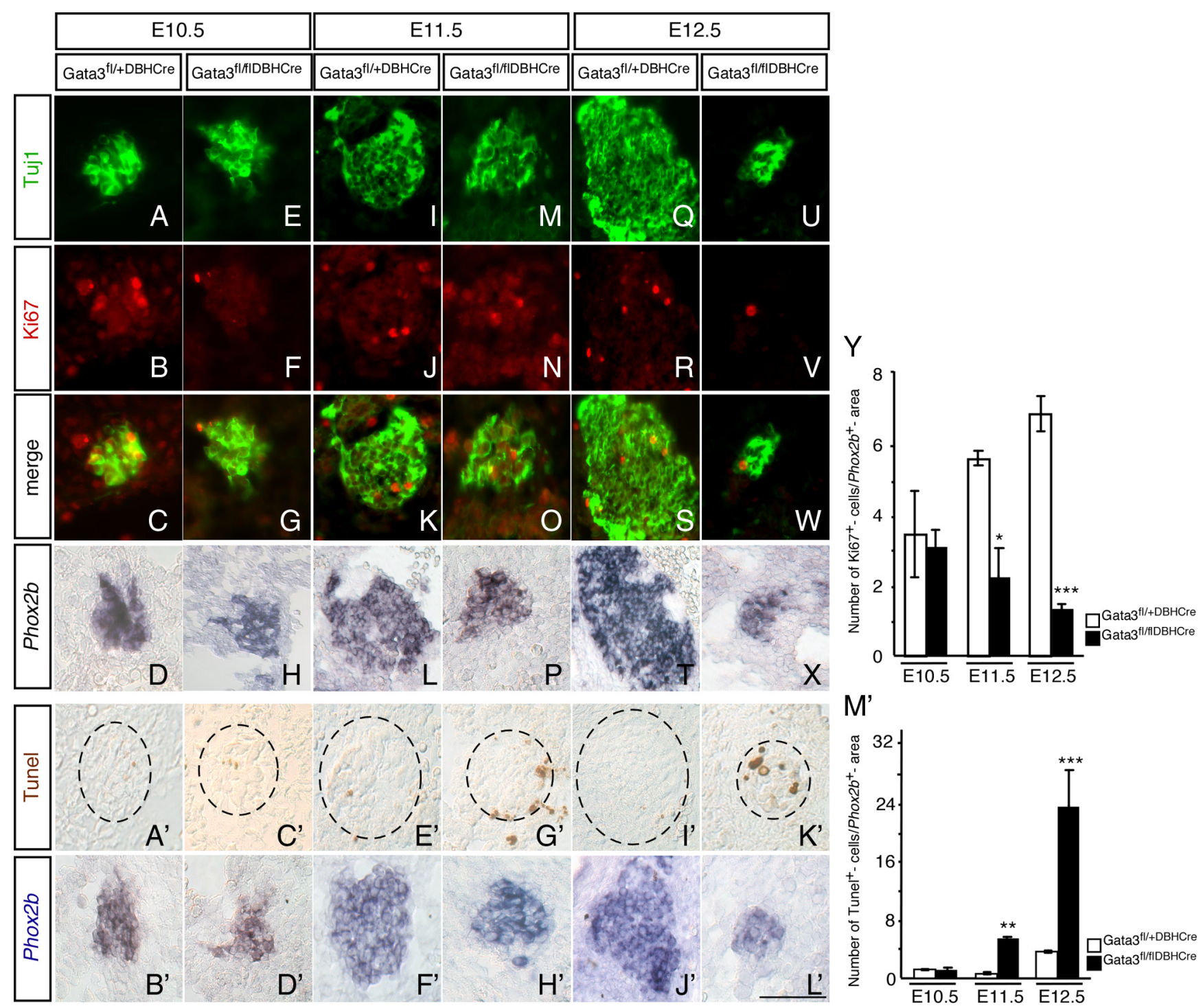

Figure 2. Proliferation and cell death analysis in Gata3 deficient mice. Double immunohistochemistry was performed for Tuj1 and Ki67 in sympathetic ganglia from the trunk region in Gata3 $^{\text {fl/fIDBHCre }}$ and control mice. The Tuj1 $(\boldsymbol{A}, \boldsymbol{E}, \boldsymbol{I}, \boldsymbol{M}, \boldsymbol{Q}, \boldsymbol{U})$ immunostaining was performed to localize the ganglia. On parallel sections the Phox2b expression $(\boldsymbol{D}, \boldsymbol{H}, \boldsymbol{L}, \boldsymbol{P}, \boldsymbol{I}, \boldsymbol{X})$ was determined by in situ hybridization. The number of Ki67-positive cells $(\boldsymbol{B}, \boldsymbol{F}, \boldsymbol{J}, \boldsymbol{N}, \boldsymbol{R}, \boldsymbol{V})$ was referred to the Phox2b-positive area $(\boldsymbol{D}, \boldsymbol{H}, \boldsymbol{L}, \boldsymbol{P}, \boldsymbol{T}, \boldsymbol{X})$. No significant change could be observed in the number of proliferating cells at E10.5 embryos $(\boldsymbol{A}-\boldsymbol{H})$. At E11.5 and E12.5, there was a strong reduction in the number of Ki67-positive cells in the conditional Gata3 mutant mice compared to controls (I-X). The number of apoptotic cells in sympathetic ganglia was analyzed by TUNEL and referred to the area of Phox2b-positive cells determined in parallel sections. AtE10.5, the number of TUNEL-positive cells is not affected in the Gata3 mutants $\left(\boldsymbol{A}^{\prime}-\boldsymbol{D}^{\prime}\right)$. The number of apoptotic cells is increased at E11.5 and E12.5 in the mutants $\left(\boldsymbol{E}^{\prime}-\boldsymbol{L}^{\prime}\right)$. The quantification of the proliferation and TUNEL is shown in $\boldsymbol{Y}$ and $\boldsymbol{M}^{\prime}$, respectively [values were significantly different compared to control mice for E11.5 and E12.5 proliferation analysis $\left({ }^{*} p<0.01, n=3 ;{ }^{* * *} p<0.0001, n=4\right)$ and for E11.5 and E12.5 TUNEL analysis ( ${ }^{* *} p<0.001, n=5$; ${ }^{* *} p<0.0001, n=4$ ) (Student's $t$ test)]. Scale bar, $100 \mu \mathrm{m}$.

conditional Gata3 mutants were rescued by noradrenalin agonists since the embryos die between E10.5-E11.5 due to noradrenalin deficiency (Pattyn et al., 2000; Tsarovina et al., 2004). In the Gata3 $3^{\mathrm{fl} / \text { DBHCreERT2 }}$ and Gata $3^{\mathrm{f} / \mathrm{flDBHCreERT2}}$ mice the Cre was activated by injecting the mice intraperitoneally with $100 \mu \mathrm{l}$ of tamoxifen diluted in corn oil $(20 \mathrm{mg} / \mathrm{ml})$ (Stubbusch, Majdazari, Schmidt, Schütz, and Rohrer, unpublished observation). Embryos obtained at E10.5-E16.5 were fixed with 4\% paraformaldehyde in $0.1 \mathrm{~m}$ sodium phosphate buffer for $6 \mathrm{~h}$. Fixative was replaced by $30 \%$ sucrose in $0.1 \mathrm{M}$ sodium phosphate buffer and the embryos were frozen at $-80^{\circ} \mathrm{C}$ in Tissue Tek (Sakura Finetek).

In situ hybridization. Nonradioactive in situ hybridization on cryosections and preparation of digoxigenin labeled probes for mouse Phox $2 b$, $T H$, and $D B H$ (gifts from J.-F. Brunet, École Normale Supérieure (ENS), Paris, France), SCG10 (gift from G. Grenningloh, Institute of Cellular Biology and Morphology, University of Lausanne, Lausanne, Switzerland), Hand 2 and Ascl1 (gift from D. J. Anderson, California Institute of Technology, Pasadena, CA), and Gata3 (gift from C. Goridis, ENS, Paris,
France) was performed as described previously (Ernsberger et al., 1997; Stanke et al., 1999).

Proliferation and TUNEL analysis. Cryosections of $12 \mu \mathrm{m}$ were collected and analyzed for the expression of the proliferation marker antiKi67 rabbit (Abcam, Cat. No. ab15580) (Hendershot et al., 2008). To localize the sympathetic ganglia on the sections, coimmunostainings with mouse anti-Tuj1 (Covance, Cat. No. MMS-435P) were performed. Alexa594 anti-rabbit and Alexa488 anti-mouse were used as secondary antibodies. The Ki67-positive cells within the ganglia were counted and referred to the Phox $2 b$-positive area determined on consecutive sections (note that there was no significant difference in the area of Phox $2 b$ - and Tuj1-expressing cells in the mutant mice). At least three embryos were analyzed for each stage. The results are given as mean \pm SEM and statistically analyzed with unpaired two-tailed Student's test.

TUNEL-positive cells were detected on cryosections using the Apoptag Plus in situ apoptosis detection kit (Millipore Bioscience Research Reagents) according to the manufacturer's instructions. To rec- 
ognize the sympathetic ganglia on the sections immunohistochemistry with mouse anti-Tuj1 was performed after the TUNEL procedure. After staining with DAB to detect the apoptotic cells, sections were washed with PBS and blocked 30 min with PBS containing 10\% horse serum and $0.2 \%$ Triton X-100. The primary antibody (mouse anti-Tuj1) was diluted in the blocking solution and incubated overnight at $4^{\circ} \mathrm{C}$. Sections were washed in PBS containing 0.2\% Triton X-100. Alexa488 anti-mouse was used as secondary antibody. Sections were covered with PBS containing $50 \%$ glycine. TUNEL-positive cells within the ganglia were counted and referred to the Phox $2 b$-positive area determined on consecutive sections. At least four embryos were analyzed for each stage. The results are given as mean \pm SEM and statistically analyzed with unpaired two-tailed Student's test.

Immunostaining. Adult SCG were isolated from Gata3 ${ }^{\text {DBHCreERT2 }}$ control and mutant mice after 3 and $5 \mathrm{~d}$ of tamoxifen injections and fixed in $4 \%$ paraformaldehyde for $2 \mathrm{~h}$. After replacing the fixative with $30 \%$ sucrose for $24 \mathrm{~h}$, the SCG were frozen in Tissue Tek at $-80^{\circ} \mathrm{C}$ and $12 \mu \mathrm{m}$ cryosections were collected and blocked 30 min with PBS containing $10 \%$ horse serum and $0.2 \%$ Triton X-100. The primary antibodies rabbit anti-TrkA (Millipore, Cat. No. 06-574) and rabbit anti-Gata3 were diluted in blocking solution and sections were incubated overnight at $4^{\circ} \mathrm{C}$. After wash steps in PBS containing 0.2\% Triton X-100, Alexa594 antirabbit was used as secondary antibody. Sections were covered with PBS containing $50 \%$ glycerol.

Semiquantitative RT-PCR analysis. Total RNA from SCG and adrenal gland obtained from adult Gata $3^{\mathrm{f} /+ \text { DBHCreERT2 }}$ and Gata $3^{\mathrm{f} / \text { flDBHCreERT2 }}$ mice was isolated using Trizol Plus RNA purification kit (Invitrogen) according to the manufacturer's instructions. cDNA from total RNA was synthesized using the Superscript III kit (Invitrogen). The cDNA was used as template for PCR amplification in a $50 \mu \mathrm{l}$ reaction (Tsarovina et al., 2004). To achieve accurate quantification, $10 \mu \mathrm{l}$ aliquots were collected during PCR run at various cycles (23-37 cycles). The PCR products were separated on $1.5 \%$ agarose gels and stained with ethidium bromide. Their fluorescence intensities were measured using the ScionImage Software version 4.03 (Scion). In all experiments, amplification of Gapdh was run in parallel to normalize the different samples. All results are given as percentage \pm SEM of control mice and at least three animals were analyzed. The RT-PCR was repeated three times with each cDNA.

Primer pairs designed for amplification of specific cDNA fragments are as follows: Gapdh_s: 5' -TGTGATGGGGTGTGAACCA-3'; Gapdh_as: 5'-GGTCCATTTCTTACT-3'; TH_s: 5'-CACGTGGAATACACAAAGGAG-3'; TH_as: 5'-GTGTACGGGTCAAACTTCAC-3'; DBH_s: 5'-CGACAATGAAGCCCTCTA CGAC-3'; DBH_as: 5'-ACTGCTCCGAGATGCGT TTG-3'; Gata3_s: 5'-GACATGGAGGTGACTGCG-3'; Gata3_as: 5'-GTGGTGGGTCGGAGGATA-3'; Bcl-2_s: 5'-CGATGGTGTGGTTGCCTTA TG-3'; Bcl-2_as: 5' -GATTCTGGTGTTTCCCCG TTG-3'; $B c{ }_{-X L \_} s: 5^{\prime}$-TCTTTCGGGATGGAGTAAACT GG-3'; Bcl ${ }_{-X L \_} a s: 5^{\prime}-\mathrm{GG}-$

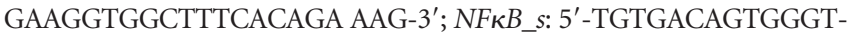
GTG GAGACA TCC-3'; NFкB_as: 5'-TAATGACAGCAGGAACC CAG CG-3'; TrkA_s: 5'-CAAGATGCTCGTGGCTGTC AAG-3'; TrkA_as: 5' TACCAGGGCTGCTTTCCAT AGG-3'; 7 75_s: $5^{\prime}$-GCACCCTCATTCGTGTCATAAGC-3'; p75_as: 5'-AGAAAGTTGCCTCAGACTGC GG-3'; TUBB3_s: 5' -CGACAATGAAGCCCTCTACG AC-3'; TUBB3_as: 5' ACTGCTCCGAGATGCGTTTG-3'; Bik_s: 5'-CACCAACCTCAGGAAAACATCTG-3'; Bik_as: 5'-GAGCAGGGGTCAAGAGAAGAAG G-3'; Bok_s: 5'-TCTTCCTGTTGTTGCCAGAGAG ATG-3'; Bok_as: 5' GCATTAGCCAGAGTCCCCTTC AG-3'; Bmf_s: 5'-TGGAGTAACAAGACATCAGCC-3'; Bmf_as: 5'-TGGGGTGGACATCAGACAAC-3'.

Sympathetic neuron cultures. Paravertebral lumbosacral sympathetic chain ganglia were isolated from E12 chicken embryos. The ganglia were dissociated chemically and mechanically as described previously (Rohrer and Thoenen, 1987). The cells ( 200,000) were electroporated (Reiff et al., 2010) with pCAGGS vector as controls or pCAGGS-dnGata2 to knock down the endogenous Gata2 expression or were cotransfected with pCAGGS-dnGata2 and pCAGGS-Bcl ${ }_{\mathrm{xL}}$ for rescue experiments using the Amaxa Nucleofector II according to the manufacturer's instructions. To remove cell debris, the cell suspension was centrifuged through a 3\% BSA step gradient as described previously (Ernsberger and Rohrer, 1988). After transfection the cells were plated on four-well culture dishes

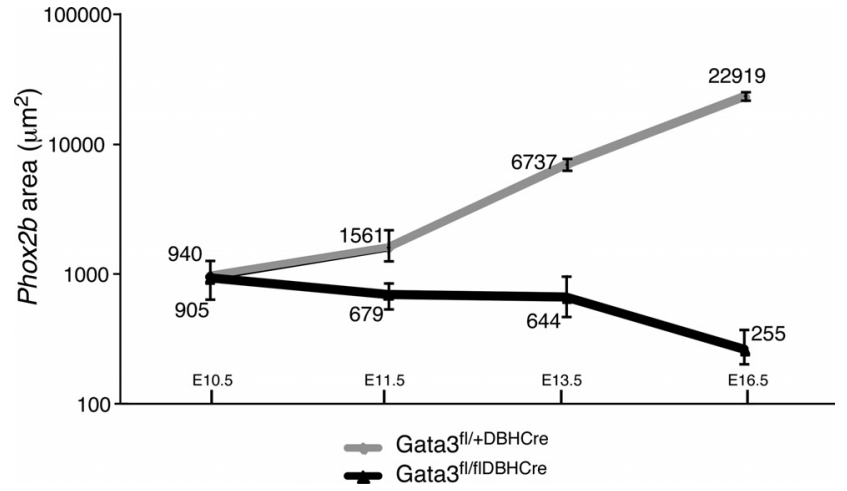

Figure 3. Comparison of sympathetic ganglion size between control and Gata $3^{\mathrm{fl} / \text { fldBHcre }}$ mice. The area of Phox $2 b$ expression was determined by in situ hybridization at the brachial and thoracic level and is graphically shown in logarithmic scale. Whereas the area of Phox $2 b$ expression in control mice increases over time (gray line), the Phox2b expression area in the mutants decreases about threefold between E10.5 and E16.5 (black line). Data represent the mean \pm SEM of at least three embryos per stage.

coated with poly-DL-ornithine (Sigma) and laminin (Invitrogen). The cells were cultured in the presence of $15 \mathrm{ng} / \mathrm{ml} \mathrm{NGF}$ or without NGF for $4 \mathrm{~d}$ at $5 \% \mathrm{CO}_{2}$ and $37^{\circ} \mathrm{C}$ in MEM containing $10 \% \mathrm{HS}, 5 \% \mathrm{FCS}, 1 \%$ glutamine, and $1 \%$ penicillin/streptomycin. In some experiments, the caspase- 3 inhibitor DEVD-CHO (5 $\mu \mathrm{M})$ was added through the culture period. Cells were then fixed with $4 \%$ paraformaldehyde in sodium phosphate buffer for $15 \mathrm{~min}$, washed with PBS, and stained for TUNEL using the in situ cell death detection kit (Roche) according to the manufacturer's protocol. TUNELpositive cells were counted on at least 20 visual fields at $40 \times$ magnification with a Zeiss Axiophot 2 microscope for each condition. Three independent experiments were statistically analyzed with paired two-tailed Student's $t$ test. The results are given as mean \pm SEM.

Morphometric analysis. The area of Phox $2 b, T H, D B H, S C G 10$, Hand2, and Ascll expression of the sympathetic ganglia in the thoracic level and the area of Phox $2 b$ and $D B H$ in the adrenal gland were imaged at $20 \times$ magnification using a Zeiss Axiophot 2 microscope and a Visitron systems spot RT3 camera. The areas were quantified morphometrically using the MetaVue (version 7.1.3.0) imaging system. The measured area was manually thresholded and determined in $\mu \mathrm{m}^{2} /$ section (Tsarovina et al., 2004; Lucas et al., 2006). At least four embryos were analyzed for each stage, and the results are given as mean area per section \pm SEM. For statistical analysis unpaired two-tailed Student's $t$ test was used.

\section{Results}

Conditional Gata3 knock-out in embryonic $D B H$-expressing neurons leads to reduced sympathetic ganglion size without affecting noradrenergic gene expression

The selective loss of $\mathrm{TH}$ expression by developing sympathetic neurons in the Gata3 $\mathrm{KO}$ revealed an essential role in the initial noradrenergic differentiation (Lim et al., 2000; Tsarovina et al., 2004; Moriguchi et al., 2006). To address the question whether Gata3 is not only required for the initiation, but also for the maintenance of $T H$ expression, we eliminated Gata3 in already differentiated, $\mathrm{DBH}$-expressing cells using Cre-recombinase expressed under the control of the $D B H$ promoter (Gata3 ${ }^{\text {DBHCre }}$ ) (Stanke et al., 2006). As DBHCre expression and subsequent excision of the Gata3 gene just starts at E10.5, no effect on the expression of Phox 2b, SCG10, DBH, TH, Hand2, Ascl1, and Gata3 is observed at that age (supplemental Fig. 1, available at www. jneurosci.org as supplemental material). This is in contrast to the full Gata3 $\mathrm{KO}$ where $T H$ and $\mathrm{DBH}$ are already massively reduced at E10.5 (Tsarovina et al., 2004; Moriguchi et al., 2006). In the following days a continuous and parallel decrease in the expression of Phox 2b, SCG10, DBH, TH, and Hand2 was evident in Gata3 ${ }^{\text {DBHCre }}$ embryos. The area of Phox $2 b$-expressing cells was 

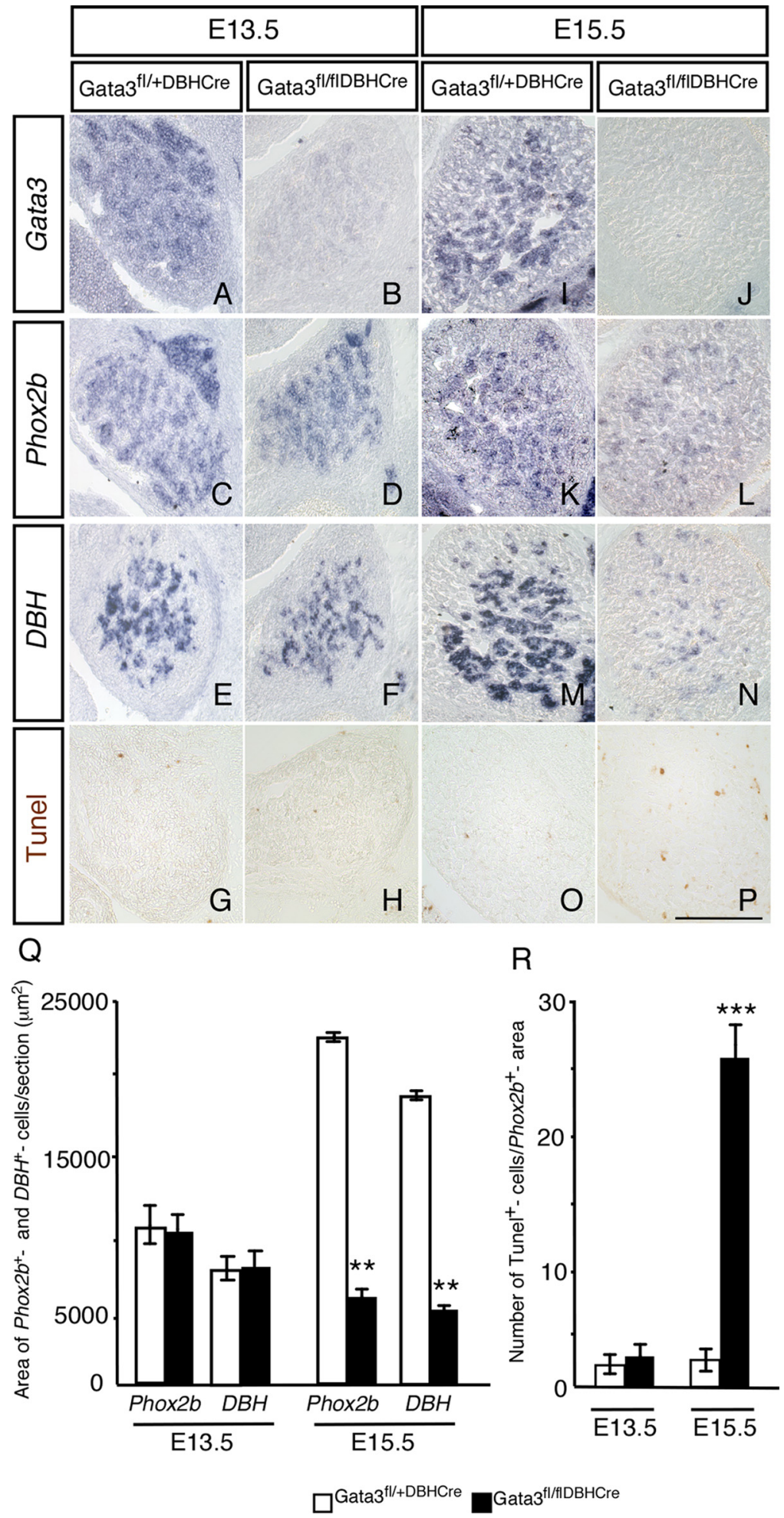

Figure 4. Conditional Gata3 knock-out in embryonic chromaffin cells. The adrenal gland was analyzed by in situ hybridization atE13.5 and E15.5 for the expression of Gata3, Phox2b, and DBH. AtE13.5, Gata3 expression $(\boldsymbol{A}, \boldsymbol{B})$ is undetectable in the chromaffin cells of Gata $3^{\text {fl/fIDBHCre }}$ mice, whereas the expression of Phox $2 b$ and DBH was unchanged $(\boldsymbol{C}-\boldsymbol{F})$. At E15.5, there is a significant decrease in both Phox $2 b$ and DBH expression areas in the adrenal gland $(\boldsymbol{K}-\boldsymbol{N})$. Gata3 expression is undetectable in the mutants $(J)$, whereas there is strong expression in control mice $(I)$. TUNEL analysis show no change in the number of apoptotic cells at E13.5 $(\mathbf{G}, \boldsymbol{H})$, whereas at E15.5 the number of TUNEL-positive cells in the mutants is strongly increased $(\boldsymbol{P})$ compared to control mice $(\mathbf{0})$. The quantification of the in situ hybridization is shown in $\boldsymbol{Q}$ and that for TUNEL in $\boldsymbol{R}$. The values in the mutants were significantly different from controls only at E15.5 $\left[n=3, p<0.001\left({ }^{* *}\right)\right.$ for the Phox2 $b$ and Dbh expression area, $p<0.0001$ (***) for TUNEL]. Scale bar, $200 \mu \mathrm{m}$. reduced already at E11.5 to $\sim 40 \pm 11 \%$, with similar effects on $H a n d 2, T H, D B H$, and SCG10 and complete lack of Gata3 (Fig. 1A-O). Only the low number of Ascl1-expressing cells was not affected. This may be explained by the immature status of these cells that may not depend on Gata3 for survival, as the sympathetic progenitors in E10.5 ganglia (Tsarovina et al., 2004). At E13.5 the area of cells expressing the autonomic lineage marker Phox $2 b$ and noradrenergic and neuronal markers was reduced in Gata $3^{\text {DBHCre }}$ mice to $<10 \%$ of controls (Fig. $\left.1 A^{\prime}-L^{\prime}, P\right)$, which is very similar to the effects observed in SCG and stellate ganglia of E13.5 Gata3 ${ }^{-1-}$ embryos (Tsarovina et al., 2004). Ascl1-expressing cells are no more detectable at this stage in both control and Gata3-deficient ganglia (data not shown). The parallel decrease of $P h o x 2 b, T H, D B H$, and SCG10 expression indicates that the elimination of Gata3 in $D B H$-expressing cells does not have a selective effect on the expression of noradrenergic marker genes but rather controls sympathetic neuron number. The similar effects observed at E13.5 in Gata $3^{-1-}$ and Gata $3^{\text {DBHCre }}$ mice demonstrates a continued Gata3 dependence of the sympathetic neuron lineage after noradrenergic differentiation.

\section{Conditional Gata3 elimination affects proliferation and survival of sympathetic ganglion cells}

Sympathetic neuron number is determined during normal development by differentiation of progenitor cells, proliferation of sympathetic progenitors as well as immature neurons, and cell death controlled by neurotrophic factors (Glebova and Ginty, 2005). We analyzed proliferation and apoptotic cell death in sympathetic ganglia of Gata $3^{\text {DBHCre }}$ and wild-type mice. Proliferation was followed by costaining for Ki67 and TuJ1, referring the proportion of proliferating cells to the Phox $2 b$-positive area determined on parallel sections. The conditional Gata3 knock-out decreased proliferation at E11.5 and E12.5 to $36 \pm 12 \%$ and $20 \pm$ $2 \%$, respectively (Fig. $2 A-Y$ ). In addition, the number of TUNEL-positive cells, which is very low in control sympathetic ganglia, was strongly increased at both E11.5 and E13.5 (Fig. $2 A^{\prime}-M^{\prime}$ ).

If Gata3-dependent proliferation represents the predominant function of Gata3 in the control of cell number, ganglion size is expected not to increase after Gata3 elimination but rather to remain stable. Since we observed that Gata3 elimination leads to a threefold decrease in the 
Phox $2 b$ area between E10.5 and E16.5, as compared to the 20-fold increase in ganglion size in controls (Fig. 3), we conclude that apoptotic cell death contributes significantly to the reduced sympathetic ganglia in Gata $3^{\text {DBHCre }}$ mice.

\section{Conditional Gata3 knock-out in embryonic DBH-expressing chromaffin cells}

The number of chromaffin cells is reduced in E13.5 $\mathrm{Gata}^{-1-}$ embryos to $\sim 20 \%$ of controls, i.e., to a similar extent as neuron numbers in the stellate ganglion and thoracic chain (Tsarovina et al., 2004; Moriguchi et al., 2006). In contrast, we now observed that in E13.5 Gata3 ${ }^{\text {DBHCre }}$ embryos the area of Phox $2 b$ - and $D B H$ expressing cells in the adrenal gland is not affected (Fig. $4 C-H, Q$ ), whereas Phox $2 b$ and $D B H$-expressing cells in sympathetic ganglia are $<10 \%$ of controls (Fig. 1). Phox $2 b$ - and $D B H$-positive chromaffin cells decrease between E13.5 and E15.5 (Fig. $4 K-N, Q$ ), which is due to cell death, as the number of apoptotic cells stained by TUNEL is strongly increased at E15.5 (Fig. $4 O, P, R)$. As $D B H$ expression in the adrenal gland is initiated at E11.5 (Gut et al., 2005), chromaffin cells are able to survive in Gata $3^{\text {DBHCre }}$ mice for several days, whereas sympathetic neurons rapidly die in the absence of Gata3. Thus, the mechanisms controlling survival of chromaffin cells and sympathetic neurons show strong differences, at least with respect to the timing of cell death. The previously observed reduction of chromaffin cells in E13.5 $\mathrm{Gata}^{-1-}$ embryos (Moriguchi et al., 2006) can be explained by a requirement of Gata3 in the survival of sympathoadrenergic progenitors before the onset of $D B H$ expression.

\section{Apoptotic death of differentiated, postmitotic sympathetic neurons upon Gata3 knockdown}

Although the use of $\mathrm{DBH}^{\mathrm{Cre}}$ restricts the effects of the Gata3 conditional knock-out to a stage when differentiation to noradrenergic cells has been accomplished, these cells still have an immature phenotype, reflected, for instance, by their ability to proliferate. To address the role of Gata transcription factors in more mature sympathetic neurons, we turned to cultures of postmitotic sympathetic neurons from E12 chick paravertebral ganglia. In chick sympathetic ganglia Gata2 but not Gata3 is expressed and represents the functional paralogue of mouse Gata3 in sympathetic ganglia (Tsarovina et al., 2004). Here, we have analyzed the effects of forced expression of dnGata2 (Tsarovina et al., 2004) on the survival of differentiated, postmitotic sympathetic neurons from E12 chick embryos. Neurons from ganglion dissociates were transfected with pCAGGS-dnGata2 or, in controls, with pCAGGS alone and the number of neurons was determined after $12 \mathrm{~h}$ and $4 \mathrm{~d}$ in the presence of NGF (Fig. $5 \mathrm{~A}$ ). After $12 \mathrm{~h}$ in culture the number of neurons in the control transfections and in cultures transfected with dnGata2 was not significantly dif-
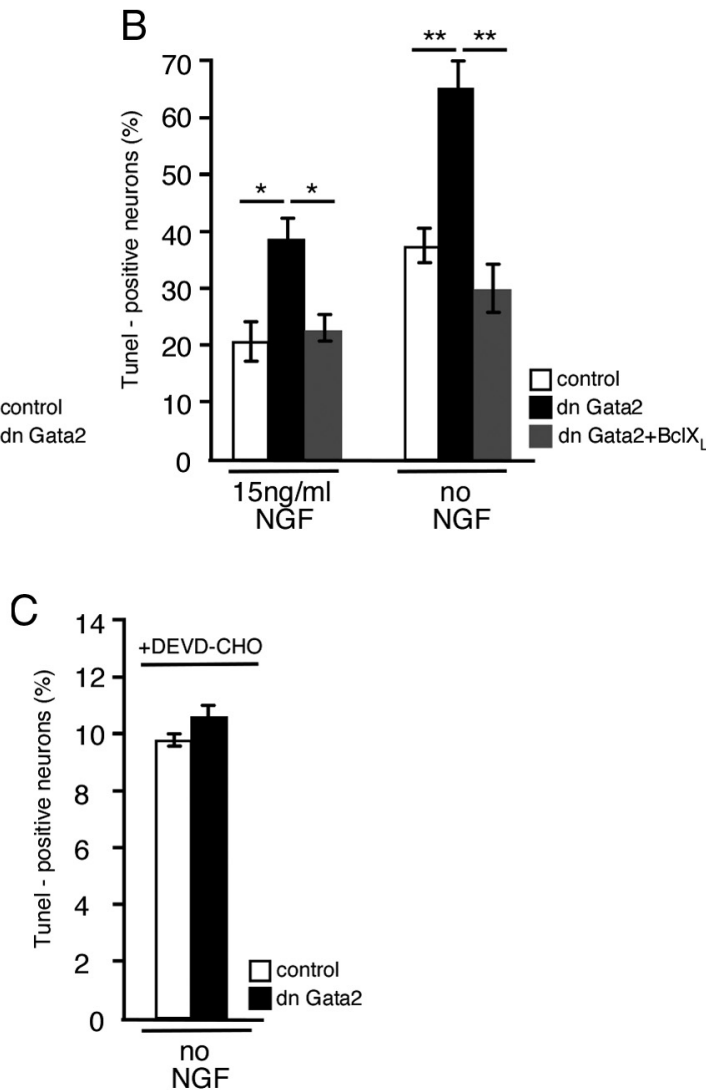

NGF

Figure 5. Inhibition of Gata2 in differentiated chick sympathetic neuron cultures leads to increased apoptosis. Sympathetic neurons from E12 chick embryos were transfected with pCAGGS or pCAGGS-dnGata2 or cotransfected with pCAGGS

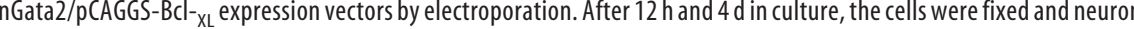
作 fferent from controls $(\boldsymbol{A})$ or that the two indicated values were significantly different from each other $(\boldsymbol{B})\left({ }^{*} p<0.01\right.$ ${ }^{* *} p<0.001, n=3$, Student's $t$ test).

ferent. After $4 \mathrm{~d}$ the number of dnGata2-transfected neurons is decreased by $31 \%$ and $42 \%$ as compared to the number of controltransfected cells and plated cells, respectively (Fig. 5A). To investigate whether this decrease is due to apoptosis, TUNEL-positive neurons were determined after a $4 \mathrm{~d}$ culture period in the presence or absence of NGF. The expression of dnGata2 lead to a strong increase in the number of TUNEL-positive neurons both in neurotrophinsupported cultures and in neurons with impaired survival due to the absence of neurotrophins (Fig. 5B). The cell death of cultured sympathetic neurons was inhibited by ectopic expression of the antiapoptotic gene $\mathrm{Bcl}_{-\mathrm{XL}}$, indicating that the dnGata2-mediated decrease of neurons is due to apoptosis. The cell death of dnGata2transfected sympathetic neurons is prevented by the apoptosis inhibitor DEVD-CHO (Fig. 5C). In the presence of DEVD-CHO, the apoptosis is more strongly inhibited than with $\mathrm{Bcl}_{\mathrm{XL}}$, suggesting that $\mathrm{BCl}_{-\mathrm{XL}}$ alone is not sufficient to completely block apoptosis and that additional anti-apoptotic genes are necessary for a complete rescue effect. The experiments indicate that dnGata 2 interferes with NGF-mediated survival and accelerates ongoing apoptosis in the absence of NGF. This result suggests that Gata2 in the chick and 


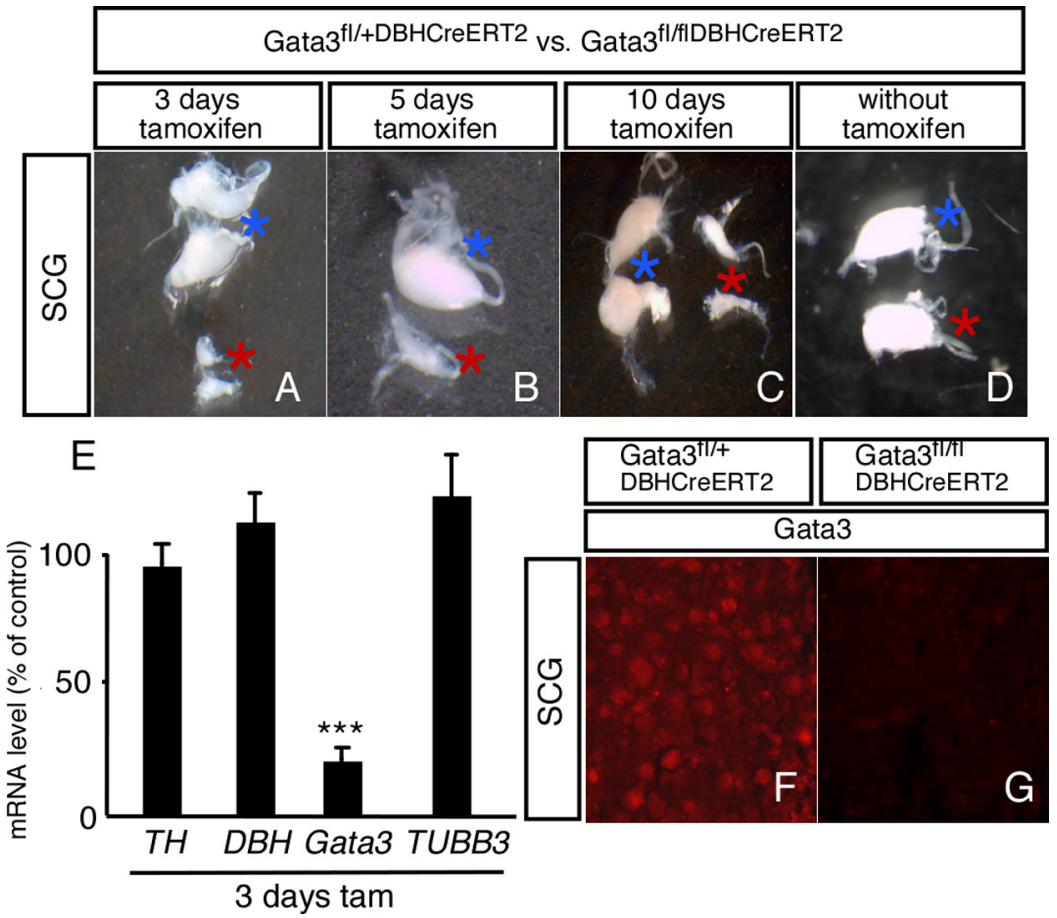

Figure 6. Adult superior cervical ganglia are strongly reduced in size after Gata3 elimination using the tamoxifen-inducible DBHCre system. Adult (P40-P60) Gata $3^{\mathrm{f} / /+\mathrm{DBHCreERT2}}$ and Gata3 ${ }^{\mathrm{f} / \text { /fDBHCreERT2 }}$ mice were injected with $100 \mu$ l of tamoxifen for 3 , 5 , and $10 \mathrm{~d}$. After 2-5 additional days, the mice were killed and the superior cervical ganglia were isolated. The size of the ganglia was dramatically reduced in the inducible Gata3 mutants ( $\boldsymbol{A}-\boldsymbol{C}$, mutants are indicated with red stars, controls with blue stars). There was no difference in the size of the SCG between mutants (red stars) and controls (blue stars) in animals without tamoxifen injection. The ganglia were also analyzed by RT-PCR (E). No significant change in the mRNA levels of $T H, D B H$, and TUBB3 was observed in the mutants after $3 \mathrm{~d}$ of tamoxifen injection $(\boldsymbol{D})$. In contrast, Gata3 mRNA levels were strongly reduced $(\boldsymbol{E})$. The immunostaining with Gata3 antibodies indicates the virtually complete loss of Gata3 protein in the mutant mice $(\boldsymbol{G})$ compared to heterozygous control animals $(\boldsymbol{F})\left[n=3\right.$ mutants, $p<0.0001\left({ }^{* *}\right)$ for Gata3 mRNA (Student's $t$ test)].
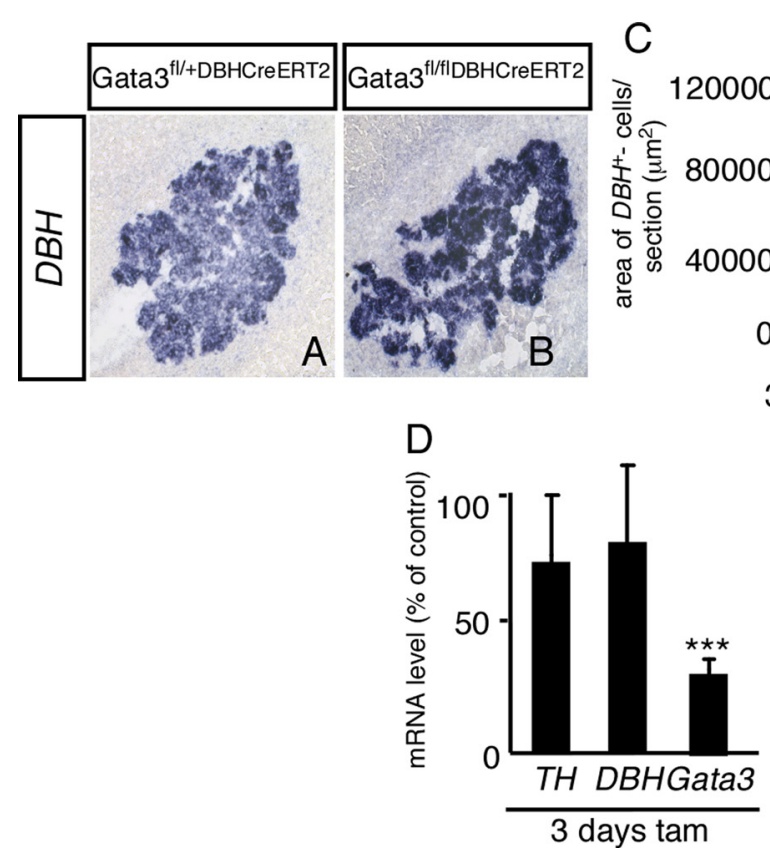

Figure 7. Conditional knock-out of Gata 3 in adult chromaffin cells. Adult (P40-P60) Gata3 ${ }^{\mathrm{fl} /+\mathrm{DBHH} \text { (reERT2 }}$ and Gata $3^{\mathrm{f} / \text { flDBHCre }}$ ERT2 mice were injected with $100 \mu$ l of tamoxifen for $3 \mathrm{~d}$. After 2 additional days, the mice were killed and the adrenal glands were analyzed for $D B H$ expression by in situ hybridization. The expression of the adrenergic marker $D B H$ was not affected in the mutants compared to control mice $(\boldsymbol{A}, \boldsymbol{B})$. The area of DBH expression was quantified in $\boldsymbol{C}$. RT-PCR analysis (D) revealed that the Gata $3 \mathrm{mRNA}$ levels were reduced in the mutants, whereas the mRNA levels of $T H$ and $D B H$ showed no significant change $(\boldsymbol{D})[n=3$ mutants,

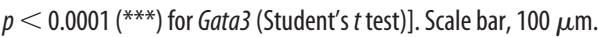

Gata3 in the mouse are essential for the survival of postmitotic sympathetic neurons.

Conditional Gata3 knock-out in adult sympathetic neurons results in rapid neuron death

The apoptotic death of cultured postmitotic sympathetic neurons upon Gata3 knockdown raised the question of whether sympathetic neuron survival depends on the persistent function of Gata3 also in the adult nervous system.

To address this issue, we generated a mouse line with a tamoxifen-inducible form of Cre under the control of the $D B H$ promoter $\left(\mathrm{DBH}^{\mathrm{CreERT}}\right)$ (Stubbusch et al., in preparation). Using RosaR26 as reporter and tamoxifen-injection for 3, 5, or $10 \mathrm{~d}$ revealed selective Cre activity in noradrenergic cells, i.e., sympathetic ganglia, adrenal chromaffin cells, and the locus ceruleus (Stubbusch et al., in preparation). Tamoxifen-induced activation of DBHCreERT2 in adult Gata $3^{\mathrm{fl} / \mathrm{fl}}$ mice resulted in a massive reduction of sympathetic ganglion size leading to small residual superior cervical ganglia (SCG) (Fig. 6) and stellate ganglia (data not shown). The remaining neuron population displayed a massive loss of Gata3 mRNA as revealed by RT-PCR analysis, which illustrates the efficient elimination of Gata3 in adult, tamoxifen-treated Gata3 ${ }^{\text {DBHCreERT2 }}$ mice (Fig. 6). The residual sympathetic neurons express normal levels of $T H, D B H$, and TUBB3 (Fig. $6 E$ ) and most likely reflect cells that are Gata3 independent since Gata3 protein is undetectable in the mutants after $3 \mathrm{~d}$ of tamoxifen injection (Fig. $6 F, G$ ). Interestingly, cell loss in the vast majority of cells proceeds very rapidly. A single tamoxifen injection was sufficient to produce significantly reduced sympathetic ganglia within $1 \mathrm{~d}$. The functional deficit in SCG after $3 \mathrm{~d}$ of tamoxifen treatment is revealed by ptosis (data not shown), reflecting the absence of sympathetic innervation of the eyelid musculature. Gata3 ${ }^{\text {DBHCreERT2 }}$ mice that are not tamoxifen injected do not display ptosis, and their sympathetic ganglia are of normal size, excluding the possibility that the DBHCreERT2 is active at low levels in the absence of tamoxifen (Fig. 6D). In conclusion, sympathetic neuron survival is continuously dependent on Gata3 function also in the mature nervous system of the adult animal.

Mature chromaffin cells in adult animals are not affected by Gata3 elimination

Gata3 is essential for the survival of sympathoadrenal progenitors and $\mathrm{DBH}$ - 
expressing sympathetic neurons from E11.5 onwards, with very low numbers of sympathetic neurons in the SCG and stellate ganglion. In contrast, $\mathrm{DBH}$-expressing chromaffin cells are not affected in E13.5 Gata3 ${ }^{\text {DBHCre }}$ mice but are decreased at E15.5 (Figs. 1, 4). The Gata3 dependence of chromaffin cells seems to have been lost in the adult animal, as the area of $D B H$ expressing chromaffin cells in the adrenal medulla was not significantly reduced in adult animals treated with tamoxifen for $3 \mathrm{~d}$ (Fig. 7). This result is confirmed by RT-PCR for $T H$ and $D B H$. The levels of Gata3 mRNA are reduced to $33 \pm 4 \%(n=3)$ after $3 \mathrm{~d}$ of tamoxifen-treatment. As the Gata3 mRNA levels in adrenals of adult Gata3 ${ }^{\text {DBHCreERT2 }}$ mice are significantly higher than in the corresponding SCG, these residual Gata3 levels may be sufficient for adrenal chromaffin survival. It should be noted, however, that chromaffin cell survival was also observed in cases with lower Gata3 mRNA levels (20\%).

\section{Mechanisms of Gata3-dependent sympathetic neuron survival in the adult animal}

To begin to address the cellular mechanisms that are involved in neuronal cell death elicited by Gata3 elimination, the expression of genes involved in the control of neuron survival was studied in sympathetic ganglia from tamoxifentreated Gata3 ${ }^{\text {DBHCreERT2 }}$ mice. Is Gata3-

dependent neuron survival linked to neurotrophin-regulated survival mechanisms? NGF-dependent sympathetic neuron survival starts at E14-E16 and adult sympathetic neurons are not dependent for their survival (Glebova and Ginty, 2005). The requirement for Gata3 before, during and after the period of NGFmediated survival argues that Gata3 affects a general aspect of the neuronal survival mechanism rather than neurotrophin-specific signaling. Indeed, there was no obvious difference in the expression of TrkA and p75 between adult sympathetic ganglia in control- and tamoxifen-treated Gata3 ${ }^{\text {DBHCreERT2 }}$ mice (Fig. 8). Although the survival of adult sympathetic neurons, in contrast to neonatal sympathetic neurons, is not dependent on neurotrophic factors (Otten et al., 1979; Gorin and Johnson, 1980), survival at both stages is maintained by similar intrinsic mechanisms (Orike et al., 2001). Death of adult sympathetic neurons is elicited by inhibition of PI3-kinase or Akt/PKB or antisense $\mathrm{Bcl}-\mathrm{x}_{\mathrm{L}}$ and antisense Bcl-2 (Orike et al., 2001). Another key component of anti-apoptotic signaling in sympathetic neurons is the transcription factor NFкB (Maggirwar et al., 1998), which is activated by neurotrophins (Bui et al., 2001) and GDNF (Encinas et al., 2008). It is unclear, however, whether $\mathrm{NF} \kappa \mathrm{B}$ is involved in the survival of mature neurotrophin-independent neurons. As transcriptional activator, Gata3 could directly or indirectly control the sustained expression of components of the anti-apoptotic signaling pathway.

To identify signals involved in the initiation or propagation phase of sympathetic neuron cell death, ganglia from adult Gata3 ${ }^{\text {DBHCreERT2 }}$ mice were isolated after $1 \mathrm{~d}$ of tamoxifen treat- ment and analyzed by RT-PCR. At that time Gata3 mRNA levels were already reduced to $\sim 14 \pm 6 \%$ (Fig. 9A). Analysis of the anti-apoptotic genes $B c l-2, B c l-x_{L}$, and $N F \kappa B$ revealed a significant reduction by $\sim 55 \%$ for $B c l-2,60 \%$ for $B c l-x_{L}$, and $65 \%$ for $N F \kappa B$ as compared to control sympathetic ganglia from tamoxifen-injected Gata3 ${ }^{\text {fl/-DBHCreERT2 }}$ mice (Fig. 9A). Besides the anti-apoptotic genes analyzed, the pro-apoptotic gene Bax is also important in regulating the survival of sympathetic neurons (White et al., 1998). Analysis of Bax in Gata3 mutant mice injected once with tamoxifen and analyzed $24 \mathrm{~h}$ later by RT-PCR showed no significant difference in mRNA levels compared to control mice (data not shown). Since Gata $3^{\text {DBHCreERT2 }}$ mice were killed $24 \mathrm{~h}$ after tamoxifen injection, it may be too early to detect effects on Bax expression. Therefore we analyzed another group of pro-apoptotic genes, the $\mathrm{BH} 3$-only proteins known to activate Bax (Adams and Cory, 2007). We choose the BH3-only proteins Bik and Bmf because of their high expression level in adult sympathetic neurons. In addition, the expression of the pro-apoptotic gene Bok, a member of the multidomain Bcl-2/ Bax-family was analyzed (Reed, 2006). Analysis of Bik, Bok, and $B m f$ shows a strong increase in the mRNA expression level compared to control mice (Fig. 9B). This result suggests that apoptotic cell death is elicited by Gata3 elimination in mature, adult sympathetic neurons, and a similar mechanism is implicated in embryonic neurons. In contrast, analysis of mature chromaffin cells by RT-PCR after $1 \mathrm{~d}$ of tamoxifen treatment showed no significant change in the expression of $B c l-2, B c l-x_{L}$, and $N F \kappa B$ as 
A

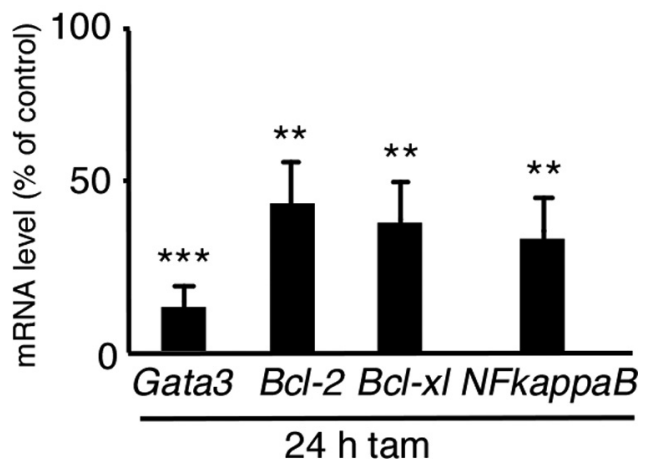

B

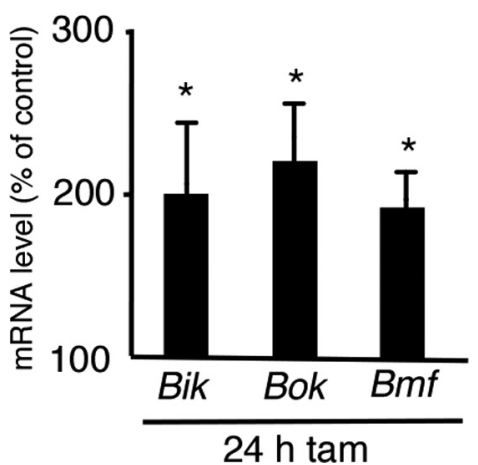

Figure 9. Analysis of anti-apoptotic and pro-apoptotic genes in adult sympathetic ganglia. Adult (P40-P60) Gata $3^{\mathrm{fl} /+ \text { DBHCreERT2 }}$ and Gata $3^{\mathrm{fl} / \text { IDBHCreERT2 }}$ mice were injected once with 100 $\mu \mathrm{l}$ of tamoxifen and killed after $24 \mathrm{~h}$. SCGs were isolated and RT-PCR was performed. Gata3 mRNA levels were reduced to $14 \pm 6 \%$ in the mutants. The mRNA levels of the anti-apoptotic genes $B C l-2, B C l-x_{L}$, and $N F \kappa B$ were also significantly reduced in mutants compared to controls $(A)$. In contrast, the expression of the pro-apoptotic genes Bik, Bok, and Bmf was increased in the mutants $(\boldsymbol{B}) . n=3$ mutants, $p<0.0001$ ( $\left.^{* *}\right)$ for Gata3; $p<0.001$ (**) $^{*}$ for $B C l-2, B C l-x_{L}$, and $N F \kappa B$; for Bik, Bok, and Bmf, $p<0.01\left(^{*}\right)$ (Student's $t$ test).

compared to control mice, although the Gata3 expression in the mutants was reduced to $30 \%$ (data not shown).

\section{Discussion}

Gata3 has important functions in the differentiation and survival of noradrenergic sympathetic neurons and chromaffin cells. Here, we show that the role of Gata3 in sympathetic neuron differentiation is restricted to initial development, whereas Gata3 is essential for survival of sympathetic progenitors and neurons throughout embryonic development up to the adult stage. This survival function seems to be largely restricted to sympathetic neurons and is only transiently observed in embryonic chromaffin cells.

\section{Gata3 in the control of noradrenergic differentiation during development and in the adult animal}

Gata3 was assigned a function in the control of noradrenergic differentiation since the initial expression of $T H$ and $D B H$ is reduced in Gata3 ${ }^{-1-}$ embryos. In addition, impaired cell survival was observed, resulting in a smaller size of sympathetic ganglia and adrenal medulla (Lim et al., 2000; Tsarovina et al., 2004; Moriguchi et al., 2006). The early cell death precluded conclusions on the role of Gata3 in the control of $\mathrm{TH}$ and $\mathrm{DBH}$ expression at later stages. The present analysis of the conditional Gata3 knock-outs at embryonic and adult stages demonstrates that Gata3 is not required for continued $T H$ and $D B H$ expression. Noradrenergic differentiation is sustained in postmitotic differ- entiated sympathetic neurons by the bHLH transcription factor Hand2 (Schmidt et al., 2009), which is also essential for initial TH expression (Hendershot et al., 2008).

Gata3 controls cell survival in the sympathetic neuron lineage The essential function of Gata3 in the survival of sympathoadrenal cells starts at early developmental stages, with decreased sympathetic ganglion size and chromaffin cell numbers in Gata $3^{-1-}$ embryos at E13.5, preceded by increased apoptosis at E11.5 (Tsarovina et al., 2004; Moriguchi et al., 2006). We now show a continued requirement of Gata3 for the survival of sympathetic neurons. In Gata3 ${ }^{\text {DBHCre }}$ embryos sympathetic ganglion size is massively decreased due to increased apoptotic cell death and decreased proliferation. The similar extent of cell loss in sympathetic ganglia of Gata3 $^{-1-}$ (Tsarovina et al., 2004; Moriguchi et al., 2006) and Gata3 ${ }^{\text {DBHCre }}$ mice suggests that Gata3 is required for the survival of sympathetic precursors as well as of differentiated, noradrenergic neurons. This requirement extends up to mature neurons in adult animals as shown by the neuron loss in the inducible Gata3 knockout and raises the question as to the molecular and cellular mechanism involved.

It has been suggested that transcription factors controlling neuronal identity coregulate subtype-specific traits and survival factor receptors. This provides a simple mechanism for the tight link between neuronal identity and survival observed for many transcription factor knock-out experiments (Morin et al., 1997). What are candidate survival factor receptors for developing sympathetic neurons? Immature, proliferating sympathetic neurons have been shown to survive independently of added neurotrophins (Ernsberger et al., 1989; Von Holst et al., 1997), which may be explained by an autocrine action of hepatocyte growth factor (HGF) (Maina et al., 1998). Subsequently, after cell cycle exit, sympathetic neurons become dependent on target-derived neurotrophic factor NGF. NGF-dependent survival starts at E15 in the mouse and extends to the early postnatal period. Adult sympathetic neurons are not dependent on neurotrophins for their survival (Otten et al., 1979; Orike et al., 2001).

Interestingly, similar intrinsic mechanisms, including PI3kinase and $\mathrm{Akt} / \mathrm{PkB}$ activation, are involved in sympathetic neuron survival during NGF-dependent and NGF-independent adult stages (Crowder and Freeman, 1998; Orike et al., 2001). PI3-kinase is also implicated in the survival function of HGF on NGF-independent early sympathetic neuroblasts (Maina et al., 2001). Inhibition of PI3-kinase and $\mathrm{Akt} / \mathrm{PkB}$ or antisense $\mathrm{Bcl}-\mathrm{x}_{\mathrm{L}}$ and $\mathrm{Bcl}-2$ results in the rapid death of cultured adult sympathetic neurons (Orike et al., 2001). The role of Bcl-2 for the survival of mature sympathetic neurons has been confirmed in vivo by the Bcl-2 knock-out (Michaelidis et al., 1996). Bcl- $\mathrm{x}_{\mathrm{L}}$ may also be active in adult sympathetic neurons, since it is required for the maintenance of other populations of mature neurons (Savitt et al., 2005; Zhang et al., 2005), in addition to its essential functions during nervous system development (Motoyama et al., 1995). $\mathrm{NF} \kappa \mathrm{B}$, which blocks apoptosis in sympathetic neurons (Maggirwar et al., 1998), is activated by neurotrophins (Bui et al., 2001) and GDNF (Encinas et al., 2008) and elicits survival through antiapoptotic target genes, including $\mathrm{Bcl}-\mathrm{x}_{\mathrm{L}}$ and inhibitors of apoptosis (IAPs) (Wiese et al., 1999; Kucharczak et al., 2003). NFкB may be activated through the PI3-kinase/Akt signaling pathway in cultured adult sympathetic neurons (Brunet et al., 2001; Orike et al., 2001), but recent data implicate an alternative activation pathway through B-Raf and IKK (Encinas et al., 2008).

Here, we provide evidence suggesting that $B c l-2, B c l-x_{L}$, and $N F \kappa B$ may act downstream of Gata3 in the maintenance of adult 
sympathetic neurons. The downregulation of anti-apoptotic regulators also suggests that apoptotic, rather than necrotic or autophagic cell death, is elicited by the elimination of Gata3. A reduction in the levels of $B c l-2, B c l-x_{L}$, and $N F \kappa B$ would also explain the apoptotic cell death induced by Gata3 elimination in embryonic sympathetic progenitors and neurons. It is presently unclear whether these genes represent direct or indirect target genes of Gata3. However, for Gata4 a direct effect on Bcl-2 regulation has been observed (Kyrönlahti et al., 2008). The finding that apoptotic cell death occurs in sympathetic neurons after Gata3 elimination is also supported by the increased expression of pro-apoptotic $\mathrm{BH} 3$-only proteins Bik and $\mathrm{Bmf}$, which activate Bax, and by the increase of the Bax-homolog Bok (Adams and Cory, 2007).

\section{Gata3 effects in differentiated sympathetic neurons and chromaffin cells}

The loss of sympathetic neurons and chromaffin cells and the reduced expression of noradrenergic marker genes in Gata3 ${ }^{-1-}$ mice could be rescued to a large extent by ectopic Gata3 expression, driven by the $D B H$ promoter (Moriguchi et al., 2006). Thus, delayed Gata3 expression in $\mathrm{DBH}$-expressing cells is sufficient to support sympathetic neuron and chromaffin cell development. The present results extend the conclusions from the rescue approach by the demonstration that Gata3 is not only sufficient but also essential for the maintenance of noradrenergic neurons. However, Gata3 is less important for the survival of embryonic $D B H$-expressing chromaffin cells, and this function seems to have been lost in adult chromaffin cells. Initial chromaffin development depends on Gata3, as shown by a 75\% reduction of adrenal chromaffin cell number in E13.5 Gata3 ${ }^{-1-}$ embryos (Moriguchi et al., 2006). However, we observed at this age no significant decrease in chromaffin cells upon Gata3 elimination in $D B H$-expressing cells. Effects on chromaffin cell survival are first seen at E15.5. This would be in agreement with previous results showing that the cell death of chromaffin cell progenitors proceeds with some delay in the adrenal as compared to sympathetic ganglia (Huber et al., 2005). In adult mice, tamoxifeninduced Gata3 elimination did not significantly affect chromaffin cells, whereas sympathetic ganglia were dramatically reduced in size. The absence of chromaffin cell loss in the adult adrenal may be explained by less efficient elimination of Gata3 in chromaffin cells as compared to sympathetic ganglia or by differences in the mechanisms controlling cell survival in these cell populations. We favor the latter explanation as chromaffin cell survival is also unaffected in mice with low residual Gata3 expression level and since chromaffin cells and sympathetic neurons indeed display distinct survival requirements (Parlato et al., 2009).

The different effects of the conditional and inducible Gata3 knock-out in sympathetic neurons and chromaffin cells also indicates that the action of Gata3 is context-dependent, a conclusion supported by the observation that Gata3 elimination in skin results in increased survival and proliferation rather than cell death (Kurek et al., 2007).

\section{The maintenance of differentiated sympathetic neurons}

Neurons must maintain their differentiated state for the lifetime of the organism. In invertebrates there is evidence that particular types of transcription factors, i.e., terminal selector genes, are required for the subtype specification during development as well as for the maintenance of neuron subtype identity. They act in an autoregulatory manner and their elimination results in the selective loss of subtype-specific marker gene expression but not in the death of neurons (Hobert, 2008). Gata3 is involved in the maintenance of the differentiated state in several non-neuronal tissues (Kouros-Mehr et al., 2006; Ho et al., 2009) but is not required for the continued expression of noradrenergic characteristics in mature sympathetic neurons.

Our findings are the first to demonstrate a selective role in neuronal survival for a transcription factor whose expression is restricted to a small number of neuronal lineages. This raises the question of whether Gata3 is controlling survival also in these other neuronal lineages. Effects on neuron survival were not observed in serotonergic neurons in the caudal raphe nuclei (van Doorninck et al., 1999; Pattyn et al., 2004) but in the inner ear, where sensory hair cells degenerate already by reducing Gata3 levels in heterozygous Gata3 ${ }^{+/-}$mice (van der Wees et al., 2004).

Another interesting issue is whether our findings reveal a mechanism to control neuron survival in general, with specific subtypes of transcription factors acting in different neuronal lineages. The delineation of such a survival control mechanism in mature neurons would be of particular interest for neuronal populations affected in neurodegenerative diseases.

\section{References}

Adams JM, Cory S (2007) Bcl-2-regulated apoptosis: mechanism and therapeutic potential. Curr Opin Immunol 19:488-496.

Brunet A, Datta SR, Greenberg ME (2001) Transcription-dependent and -independent control of neuronal survival by the PI3K-Akt signaling pathway. Curr Opin Neurobiol 11:297-305.

Bui NT, Livolsi A, Peyron JF, Prehn JH (2001) Activation of nuclear factor kappaB and $\mathrm{Bcl}-\mathrm{x}$ survival gene expression by nerve growth factor requires tyrosine phosphorylation of IkappaBalpha. J Cell Biol 152:753-764.

Cheng L, Samad OA, Xu Y, Mizuguchi R, Luo P, Shirasawa S, Goulding M, Ma Q (2005) Lbx1 and Tlx3 are opposing switches in determining GABAergic versus glutamatergic transmitter phenotypes. Nat Neurosci 8:1510-1515.

Crowder RJ, Freeman RS (1998) Phosphatidylinositol 3-kinase and Akt protein kinase are necessary and sufficient for the survival of nerve growth factor-dependent sympathetic neurons. J Neurosci 18:2933-2943.

Encinas M, Rozen EJ, Dolcet X, Jain S, Comella JX, Milbrandt J, Johnson EM Jr (2008) Analysis of Ret knockin mice reveals a critical role for IKKs, but not PI 3-K, in neurotrophic factor-induced survival of sympathetic neurons. Cell Death Differ 15:1510-1521.

Ernsberger U, Rohrer H (1988) Neuronal precursor cells in chick dorsal root ganglia: differentiation and survival in vitro. Dev Biol 126:420-432.

Ernsberger U, Edgar D, Rohrer H (1989) The survival of early chick sympathetic neurons in vitro is dependent on a suitable substrate but independent of NGF. Dev Biol 135:250-262.

Ernsberger U, Patzke H, Rohrer H (1997) The developmental expression of choline acetyltransferase (ChAT) and the neuropeptide VIP in chick sympathetic neurons: evidence for different regulatory events in cholinergic differentiation. Mech Dev 68:115-126.

Glebova NO, Ginty DD (2005) Growth and survival signals controlling sympathetic nervous system development. Annu Rev Neurosci 28:191-222.

Goridis C, Rohrer H (2002) Specification of catecholaminergic and serotonergic neurons. Nat Rev Neurosci 3:531-541.

Gorin PD, Johnson EM Jr (1980) Effects of exposure to nerve growth factor antibodies on the developing nervous system of the rat: an experimental autoimmune approach. Dev Biol 80:313-323.

Guillemot F (2007) Spatial and temporal specification of neural fates by transcription factor codes. Development 134:3771-3780.

Gut P, Huber K, Lohr J, Brühl B, Oberle S, Treier M, Ernsberger U, Kalcheim C, Unsicker K (2005) Lack of an adrenal cortex in Sfl mutant mice is compatible with the generation and differentiation of chromaffin cells. Development 132:4611-4619.

Hendershot TJ, Liu H, Clouthier DE, Shepherd IT, Coppola E, Studer M, Firulli AB, Pittman DL, Howard MJ (2008) Conditional deletion of Hand 2 reveals critical functions in neurogenesis and cell type-specific gene expression for development of neural crest-derived noradrenergic sympathetic ganglion neurons. Dev Biol 319:179-191.

Ho IC, Tai TS, Pai SY (2009) GATA3 and the T-cell lineage: essential func- 
tions before and after T-helper-2-cell differentiation. Nat Rev Immunol 9:125-135.

Hobert O (2008) Regulatory logic of neuronal diversity: terminal selector genes and selector motifs. Proc Natl Acad Sci U S A 105:20067-20071.

Huber K, Karch N, Ernsberger U, Goridis C, Unsicker K (2005) The role of Phox2B in chromaffin cell development. Dev Biol 279:501-508.

Huber K, Kalcheim C, Unsicker K (2009) The development of the chromaffin cell lineage from the neural crest. Auton Neurosci 151:10-16.

Kala K, Haugas M, Lilleväli K, Guimera J, Wurst W, Salminen M, Partanen J (2009) Gata2 is a tissue-specific post-mitotic selector gene for midbrain GABAergic neurons. Development 136:253-262.

Karis A, Pata I, van Doorninck JH, Grosveld F, de Zeeuw CI, de Caprona D, Fritzsch B (2001) Transcription factor GATA-3 alters pathway selection of olivocochlear neurons and affects morphogenesis of the ear. J Comp Neurol 429:615-630.

Kouros-Mehr H, Slorach EM, Sternlicht MD, Werb Z (2006) GATA-3 maintains the differentiation of the luminal cell fate in the mammary gland. Cell 127:1041-1055.

Kucharczak J, Simmons MJ, Fan Y, Gélinas C (2003) To be, or not to be: NF-kappaB is the answer-role of Rel/NF-kappaB in the regulation of apoptosis. Oncogene 22:8961-8982.

Kurek D, Garinis GA, van Doorninck JH, van der Wees J, Grosveld FG (2007) Transcriptome and phenotypic analysis reveals Gata3-dependent signalling pathways in murine hair follicles. Development 134:261-272.

Kyrönlahti A, Rämö M, Tamminen M, Unkila-Kallio L, Butzow R, Leminen A, Nemer M, Rahman N, Huhtaniemi I, Heikinheimo M, Anttonen M (2008) GATA-4 regulates Bcl-2 expression in ovarian granulosa cell tumors. Endocrinology 149:5635-5642.

Lim K-C, Lakshmanan G, Crawford SE, Gu Y, Grosveld F, Engel JD (2000) Gata3 loss leads to embryonic lethality due to noradrenaline deficiency of the sympathetic nervous system. Nat Genet 25:209-212.

Lucas ME, Müller F, Rüdiger R, Henion PD, Rohrer H (2006) The bHLH transcription factor hand 2 is essential for noradrenergic differentiation of sympathetic neurons. Development 133:4015-4024.

Maggirwar SB, Sarmiere PD, Dewhurst S, Freeman RS (1998) Nerve growth factor-dependent activation of NF- $\kappa \mathrm{B}$ contributes to survival of sympathetic neurons. J Neurosci 18:10356-10365.

Maina F, Hilton MC, Andres R, Wyatt S, Klein R, Davies AM (1998) Multiple roles for hepatocyte growth factor in sympathetic neuron development. Neuron 20:835-846.

Maina F, Panté G, Helmbacher F, Andres R, Porthin A, Davies AM, Ponzetto C, Klein R (2001) Coupling Met to specific pathways results in distinct developmental outcomes. Mol Cell 7:1293-1306.

Michaelidis TM, Sendtner M, Cooper JD, Airaksinen MS, Holtmann B, Meyer M, Thoenen H (1996) Inactivation of $b c l-2$ results in progressive degeneration of motoneurons, sympathetic and sensory neurons during early postnatal development. Neuron 17:75-89.

Mori T, Tanaka K, Buffo A, Wurst W, Kühn R, Götz M (2006) Inducible gene deletion in astroglia and radial glia-a valuable tool for functional and lineage analysis. Glia 54:21-34.

Moriguchi T, Takako N, Hamada M, Maeda A, Fujioka Y, Kuroha T, Huber RE, Hasegawa SL, Rao A, Yamamoto M, Takahashi S, Lim KC, Engel JD (2006) Gata3 participates in a complex transcriptional feedback network to regulate sympathoadrenal differentiation. Development 133:3871-3881.

Morikawa Y, D’Autréaux F, Gershon MD, Cserjesi P (2007) Hand2 determines the noradrenergic phenotype in the mouse sympathetic nervous system. Dev Biol 307:114-126.

Morikawa Y, Zehir A, Maska E, Deng C, Schneider MD, Mishina Y, Cserjesi P (2009) BMP signaling regulates sympathetic nervous system development through Smad4-dependent and -independent pathways. Development 136:3575-3584.

Morin X, Cremer H, Hirsch MR, Kapur RP, Goridis C, Brunet JF (1997) Defects in sensory and autonomic ganglia and absence of locus coeruleus in mice deficient for the homeobox gene Phox2a. Neuron 18:411-423.

Motoyama N, Wang F, Roth KA, Sawa H, Nakayama K, Nakayama K, Negishi I, Senju S, Zhang Q, Fujii S, Loh DY (1995) Massive cell death of immature hematopoietic cells and neurons in Bcl-x-deficient mice. Science 267:1506-1510.

Orike N, Middleton G, Borthwick E, Buchman V, Cowen T, Davies AM (2001) Role of PI 3-kinase, Akt and Bcl-2-related proteins in sustaining the survival of neurotrophic factor-independent adult sympathetic neurons. J Cell Biol 154:995-1005.

Otten U, Goedert M, Schwab M, Thibault J (1979) Immunization of adult rats against $25 \mathrm{~S}$ NGF: effects on the peripheral nervous system. Brain Res 176:79-90.

Parlato R, Otto C, Begus Y, Stotz S, Schütz G (2007) Specific ablation of the transcription factor CREB in sympathetic neurons surprisingly protects against developmentally regulated apoptosis. Development 134:1663-1670.

Parlato R, Otto C, Tuckermann J, Stotz S, Kaden S, Gröne HJ, Unsicker K, Schütz G (2009) Conditional inactivation of glucocorticoid receptor gene in dopamine-beta-hydroxylase cells impairs chromaffin cell survival. Endocrinology 150:1775-1781.

Pattyn A, Morin X, Cremer H, Goridis C, Brunet J-F (1999) The homeobox gene Phox $2 \mathrm{~b}$ is essential for the development of all autonomic derivatives of the neural crest. Nature 399:366-370.

Pattyn A, Goridis C, Brunet JF (2000) Specification of the central noradrenergic phenotype by the homeobox gene Phox $2 b$. Molecular and Cellular Neuroscience 15:235-243.

Pattyn A, Simplicio N, van Doorninck JH, Goridis C, Guillemot F, Brunet J-F (2004) Ascl1/mash1 is required for the development of central serotonergic neurons. Nat Neurosci 7:589-595.

Pattyn A, Guillemot F, Brunet JF (2006) Delays in neuronal differentiation in Mash1/Ascl1 mutants. Dev Biol 295:67-75.

Reed JC (2006) Proapoptotic multidomain Bcl-2/Bax-family proteins: mechanisms, physiological roles, and therapeutic opportunities. Cell Death Differ 13:1378-1386.

Reiff T, Tsarovina K, Majdazari A, Schmidt M, del Pino I, Rohrer H (2010) Neuroblastoma Phox $2 \mathrm{~b}$ variants stimulate proliferation and dedifferentiation of immature sympathetic neurons. J Neurosci 30:905-915.

Rohrer H, Thoenen H (1987) Relationship between differentiation and terminal mitosis: chick sensory and ciliary neurons differentiate after terminal mitosis of precursor cells whereas sympathetic neurons continue to divide after differentiation. J Neurosci 7:3739-3748.

Savitt JM, Jang SS, Mu W, Dawson VL, Dawson TM (2005) Bcl-x is required for proper development of the mouse substantia nigra. J Neurosci 25:6721-6728.

Schmidt M, Lin S, Pape M, Ernsberger U, Stanke M, Kobayashi K, Howard MJ, Rohrer H (2009) The bHLH transcription factor Hand2 is essential for the maintenance of noradrenergic properties in differentiated sympathetic neurons. Dev Biol 329:191-200.

Stanke M, Junghans D, Geissen M, Goridis C, Ernsberger U, Rohrer H (1999) The Phox2 homeodomain proteins are sufficient to promote the development of sympathetic neurons. Development 126:4087-4094.

Stanke M, Duong CV, Pape M, Geissen M, Burbach G, Deller T, Gascan H, Otto C, Parlato R, Schütz G, Rohrer H (2006) Target-dependent specification of the neurotransmitter phenotype: cholinergic differentiation of sympathetic neurons is mediated in vivo by gp130 signaling. Development 133:141-150.

Tsarovina K, Pattyn A, Stubbusch J, Müller F, van der Wees J, Schneider C, Brunet J-F, Rohrer H (2004) Essential role of Gata transcription factors in sympathetic neuron development. Development 131:4775-4786.

van der Wees J, van Looij MA, de Ruiter MM, Elias H, van der Burg H, Liem SS, Kurek D, Engel JD, Karis A, van Zanten BG, de Zeeuw CI, Grosveld FG, van Doorninck JH (2004) Hearing loss following Gata3 haploinsufficiency is caused by cochlear disorder. Neurobiol Dis 16:169-178.

van Doorninck JH, van der Wees J, Karis A, Goedknegt E, Engel JD, Coesmans M, Rutteman M, Grosveld F, De Zeeuw CI (1999) GATA-3 is involved in the development of serotonergic neurons in the caudal raphe nuclei. J Neurosci 19:RC12(1-8).

Von Holst A, Lefcort F, Rohrer H (1997) TrkA expression levels of sympathetic neurons correlate with NGF-dependent survival during development and after treatment with retinoic acid. Eur J Neurosci 9:2169-2177.

White FA, Keller-Peck CR, Knudson CM, Korsmeyer SJ, Snider WD (1998) Widespread elimination of naturally occurring neuronal death in Baxdeficient mice. J Neurosci 18:1428-1439.

Wiese S, Digby MR, Gunnersen JM, Götz R, Pei G, Holtmann B, Lowenthal J, Sendtner M (1999) The anti-apoptotic protein ITA is essential for NGFmediated survival of embryonic chick neurons. Nat Neurosci 2:978-983.

Wildner H, Gierl MS, Strehle M, Pla P, Birchmeier C (2008) Insm1 (IA-1) is a crucial component of the transcriptional network that controls differentiation of the sympatho-adrenal lineage. Development 135:473-481.

Zhang J, Chen YB, Hardwick JM, Miller MI, Plachez C, Richards LJ, Yarowsky P, van Zijl P, Mori S (2005) Magnetic resonance diffusion tensor microimaging reveals a role for $\mathrm{Bcl}-\mathrm{x}$ in brain development and homeostasis. J Neurosci 25:1881-1888. 